\title{
Stress and Depression in the Workplace of Educators in the Philippines
}

\author{
Caren Casama Orlanda-Ventayen \\ Pangasinan State University, Alaminos City Campus \\ Randy Joy Magno Ventayen \\ Pangasinan State University, Lingayen Campus
}

\section{Biodata}

Caren Casama Orlanda-Ventayen is a core faculty Bachelor of Elementary Education (BEEd) and General Education Department of Pangasinan State University, Alaminos City Campus. A graduate of Master of Arts in Education major in Educational Management. She finished her Bachelor's degree in Elementary Education at the Adelphi College in Lingayen, Pangasinan, and Bachelor of Secondary Education major in Technology and Livelihood Education at PSU Lingayen Campus.

Email: cventayen@psu.edu.ph

Randy Joy Magno Ventayen is the current Director for Public Relations, Publiction and Information of Pangasinan State University. He is also a faculty of PSU Open University Systems, PSU Lingayen Campus and a mobile faculty of PSU Binmaley Campus. He Graduated his Doctoral Degree in Business Administration in 2010 and Doctor in Information Technology at the University of the Cordilleras in consortium with Ateneo de Manila University in 2019. He served as the University Web Administrator of Pangasinan State University in 2016 to 2018, and the former Dean of the College of Business and Public Administration of PSU Lingayen Campus.

Email: dayjx@yahoo.com

\section{Abstract}

Workplace Stress and depression should be treated properly in order to maintain productive teaching as the noblest profession. Unmanaged stress and depression could lead to a serious outcome that affects the happy environment in the classroom. Thus, managing stress and avoiding depression in the workplace is one of the important situations that a teacher should NOTE: This preprint reports new research that has not been certified by peer review and should not be used to guide clinical practice. 
medRxiv preprint doi: https://doi.org/10.1101/2021.04.22.21254017; this version posted April 25, 2021. The copyright holder for this preprint (which was not certified by peer review) is the author/funder, who has granted medRxiv a license to display the preprint in perpetuity.

It is made available under a CC-BY-NC-ND 4.0 International license .

aim in order to succeed. This study aims to determine the level of workplace stress and depression of the educators in the Philippines by gathering their profile, workplace stress, and the state of depression. A correlation was investigated if there is a significant difference in the profile to the workplace stress and state of depression. Based on the result of the study, teachers sometimes experience stress in the workplace, while some experience depression at some point in time. It is recommended that teachers should understand how to practice stress management and avoiding depression.

Keywords: English, academic performance

\section{Introduction and Background of the Study}

Teaching is the noblest profession because it is the source of all professionals in the world. Without teachers, there will be no knowledge that was imparted and transferred. In order to continuously improved the educational system, healthy teachers are needed to maintain a happy environment in the classroom. Thus, managing stress in the workplace is one of the important situations that a teacher should aim in order to succeed. Academic Workload should also be manageable to maximize the productivity of the teachers.

A few numbers of the suicide of Teachers in the Philippines provides alarming results in the education sector in the Philippines (BusinessMirror, 2018). Based on several media reports, the Department of Education is mourning over the death of a teacher and say that they will look into it and it is non-work related. The Department also clarifies that the workload should not be blamed for the teacher's suicide because there are other factors that may contribute (Mateo, 2018; Reyes, 2018). While The Teachers' Dignity Coalition (TDC) met with DepEd officials to discuss concerns over the supposed workload, it cited that the heavy burden of paperwork is one among the reasons of the teacher who hanged herself in one case of teachers' suicide in 2018. (Mateo, 2018).

While the education sector refuses to correlate workload with the suicides, they still emphasize that it is a wake-up call for public school teachers to learn how to manage work pressures that reacting to news circulating on social media that heavy paperwork had prompted one multi-grade teacher to commit suicide. The Department of Education urged to 
medRxiv preprint doi: https://doi.org/10.1101/2021.04.22.21254017; this version posted April 25, 2021. The copyright holder for this preprint (which was not certified by peer review) is the author/funder, who has granted medRxiv a license to display the preprint in perpetuity.

It is made available under a CC-BY-NC-ND 4.0 International license .

lighten teacher workloads (Hernando-Malipot, 2018). Due to the numerous reports, the secretary of the Department of Education said that they have already reduced the workload of teachers, which includes clerical and paper works. The secretary added that they are currently studying how to unload further teachers, based on the news report (Terrazola, 2018).

\subsection{The Objective of the Study}

This study aims to determine the sentiments of primary and secondary school by gathering the teacher's profile, Workplace Stress, and the State of Depression. A correlation will be investigated if there is a significant difference in the profile to the workplace stress and state of depression. This study also aims to ask teachers all over the country on their workloads and perception about teacher's depression.

\subsection{Statement of the Problem}

1. What is the profile of the respondents in terms of:
a. Age
b. Sex
c. Employment Status
d. Employment Type
e. Teaching Level
f. Level of Education
g. Salary Range
h. Length of Service
i. Region

2. What is the level of workplace stress?

3. What is the level of Depression Assessment?

4. Is there a significant difference between the profile of the respondents and workplace stress?

5. Is there a significant difference between the profile of the respondents and the depression assessment?

\section{Literature Review}

Teachers are the ones who teach the students to be the best they can be; they should also be a role model for the student. In most cases, teachers are helping the students to avoid 
medRxiv preprint doi: https://doi.org/10.1101/2021.04.22.21254017; this version posted April 25, 2021. The copyright holder for this preprint (which was not certified by peer review) is the author/funder, who has granted medRxiv a license to display the preprint in perpetuity.

It is made available under a CC-BY-NC-ND 4.0 International license.

wrong thinking such as depression (Shilubane et al., 2015). One result of the study shows that teachers overwhelmingly agreed that they should have a role in suicide prevention (Hatton et al., 2017).

Teachers' suicide is not new; there have been reported cases in the past such as the 3 Chinese teachers in Hong Kong in 1994, which were preceded by the suicides of several students. In the investigated study, teachers are said to have a greater workload in addressing the needs of more troubled students, which may increase their stress levels. (Leung, 1994).

Non-teaching career is not excluded from the historical problems of suicide. Several studies conducted that linking workload in depression and suicidal thoughts. One study shows a review of studies of stress and occupational difficulties experienced by veterinary surgeons. The results show that Occupational stressors included long working hours, heavy workload, poor work-life balance, difficult client relations are stressors that contribute to depression and suicidal thoughts. (Mendoza, 2019a, 2019b; Platt et al., 2012).

Despite the reported cases in the Philippines, the result of the study is different from the United States of America, where teachers have the lowest suicide rate of any profession. While Workers in farming, fishing, and forestry jobs had the highest rate: 84.5 per 100,000 workers, the suicide rate among people in education, training and library jobs was 7.5 per 100,000 workers (McIntosh et al., 2016; Tiesman et al., 2015). Comparing the workload in the United States teachers, predictably, U.S. teachers also spend more time teaching in the classroom than their international one study shows that U.S. teachers in grades 10 through 12 spent an average of 1,076 hours teaching students each year, while the global average is just 655 hours (Organisation for Economic Co-operation and Development, 2007, 2012, 2014). Based on the study, the working hours of teachers outside the Philippines are 3 to 5 hours a day. The report covers all 34 OECD member countries as well as ten partner countries (Moeny, 2014).

\subsection{The workload of Educators in the Philippines}

When we say Educators in the Philippines, we are referring to all with a teaching career that includes teachers, instructors, and professors. Elementary Teachers are teaching from Grade 1 to 8, Junior High School Teachers are teaching Grade 9 to 10, and Senior High School Teachers are teaching Grade 11 and 12 (Department of Education, 2009). Those teaching in the Vocational Programs and Higher Educational Institutions are called 
medRxiv preprint doi: https://doi.org/10.1101/2021.04.22.21254017; this version posted April 25, 2021. The copyright holder for this preprint (which was not certified by peer review) is the author/funder, who has granted medRxiv a license to display the preprint in perpetuity.

It is made available under a CC-BY-NC-ND 4.0 International license .

Instructors or Professors depending on the rank (Department of Budget Management, 2012). The regular workload for Teachers is 6 hours a day or 30 hours a week for a full-time teacher, which still excludes other functions as a teacher (Department of Education, 2009). While in State University and Colleges, a typical full-time Instructor or Professor is handling 18 hours teaching load per week with full time teaching time excluding designation, research, and extension function. SUC professors are de-loaded by corresponding other functions such as research, extension (Tarlac State University, 2008) and privilege in ongoing graduate education. There are some faculties in the State University that has a maximum of 3 to 6 hours a week teaching load because of full-time Graduate Schooling (Commission on Higher Education, 2016) due to the K to 12 Transition in the Philippines.

\subsection{Synthesis of Literature Review}

Based on the brief literature review, it can be seen that stress and depression in the workplace can be caused by a heavy academic workload. Despite this, there are other factors that affect the actions, stress and depression can be a triggering factor. In the United States, the teacher has the lowest suicidal rate. A workload of teachers in the United States is higher than other OECD countries which are around 3 to 5 hours a day, while in the Philippines the regular workload of a teacher is 6 to 8 hours a day for Elementary and Secondary teachers and 3 to 4 hours a day for State University Instructors or Professors excluding research and extension function.

\section{Methodology}

The target respondents of this study are all the educators in the Philippines. All teachers are invited to participate in the survey by answering an online form that was distributed in CHED K to 12 Program Scholars group, TESDA Teachers group, and DepEd Tambayan Facebook Group. Purposive and convenience sampling was used in order to gather the respondents.

Participants were requested to complete the survey by posting the link in the three Facebook groups. The researcher shortens the link using bit.ly. The survey questionnaire was floated using Google Forms, and extracted in CSV format for analysis. 
medRxiv preprint doi: https://doi.org/10.1101/2021.04.22.21254017; this version posted April 25, 2021. The copyright holder for this preprint (which was not certified by peer review) is the author/funder, who has granted medRxiv a license to display the preprint in perpetuity.

It is made available under a CC-BY-NC-ND 4.0 International license.

\subsection{Statistical Treatment Used}

Frequency and Percentage were used in the primary objectives such as the profile of the respondents. Average weighted mean was also used in determining the interpretation based on the Likert rating scale used.

Table 1 Likert Scale Used

\begin{tabular}{|l|l|l|}
\hline Range & $\begin{array}{l}\text { Descriptive } \\
\text { Equivalent }\end{array}$ & $\begin{array}{l}\text { Descriptive } \\
\text { Equivalent }\end{array}$ \\
\hline 3.25 to 4.00 & Strongly Agree & Often \\
\hline 2.50 to 3.24 & Agree & Sometimes \\
\hline 1.75 to 2.49 & Disagree & Seldom \\
\hline 1.00 to 1.74 & Strongly Disagree & Never \\
\hline
\end{tabular}

For the last problem, A Pearson correlation was also used and measured Correlation that is significant at the 0.05 level (2-tailed). In order to simplify statistical computation, all data was inputted into the software SPSS for faster analysis of data.

\section{The result of the Study}

The result part of the study determines the sentiments of primary and secondary school by gathering the teacher's profile, Workplace Stress, and the State of Depression. A Correlation will be investigated if there is a significant difference in the profile to the workplace stress and state of depression.

\section{Profile of Respondents}

The majority of the respondents are female with 74 percent of the total respondents. This implies that there are more female educators in the Philippines compared to male educators.

Table 2 Frequency and Percentage distribution of respondents in terms of sex

\begin{tabular}{|l|c|c|}
\hline \multicolumn{1}{|c|}{ Sex } & Frequency & Percentage \\
\hline Male & 106 & 26 \\
\hline Female & 301 & 74 \\
\hline TOTAL & $\mathbf{4 0 7}$ & $\mathbf{1 0 0}$ \\
\hline
\end{tabular}

As shown in the table, the majority of the respondents with a 92.1 percent have the security of tenure. 
medRxiv preprint doi: https://doi.org/10.1101/2021.04.22.21254017; this version posted April 25, 2021. The copyright holder for this preprint (which was not certified by peer review) is the author/funder, who has granted medRxiv a license to display the preprint in perpetuity.

It is made available under a CC-BY-NC-ND 4.0 International license.

Table 3 Frequency and Percentage Distribution of Respondents according to Employment Status

\begin{tabular}{|l|c|c|}
\hline \multicolumn{1}{|c|}{ Employment Status } & Frequency & Percentage \\
\hline Regular/Permanent & 375 & 92.1 \\
\hline Probationary/Temporary & 13 & 3.2 \\
\hline $\begin{array}{l}\text { Contractual/Contract of } \\
\text { Service/Part-Time }\end{array}$ & 19 & 4.7 \\
\hline TOTAL & $\mathbf{4 0 7}$ & $\mathbf{1 0 0}$ \\
\hline
\end{tabular}

As shown in Table 4, the Majority of the respondents are working in the government sector.

Table 4 Frequency and Percentage Distribution of Respondents in terms of Length Employment Type

\begin{tabular}{|l|c|c|}
\hline \multicolumn{1}{|c|}{ Employment Type } & Frequency & Percentage \\
\hline Government & 369 & 90.7 \\
\hline Private & 38 & 9.3 \\
\hline TOTAL & $\mathbf{4 0 7}$ & $\mathbf{1 0 0}$ \\
\hline
\end{tabular}

The teaching level of educators in the Philippines is distributed from the kindergarten level to the tertiary level.

Table 5 Frequency and Percentage Distribution of Respondents in terms of Teaching Level

\begin{tabular}{|l|c|c|}
\hline \multicolumn{1}{|c|}{ Teaching Level } & Frequency & Percentage \\
\hline Kindergarten & 6 & 1.5 \\
\hline Elementary (Grade 1 to 3) & 55 & 13.5 \\
\hline Elementary (Grade 4 to 8) & 96 & 23.6 \\
\hline $\begin{array}{l}\text { Junior High School (Grade } \\
9 \text { and 10) }\end{array}$ & 89 & 21.9 \\
\hline $\begin{array}{l}\text { Senior High School (Grade } \\
11 \text { and 12) }\end{array}$ & 77 & 18.9 \\
\hline Vocational Level & 45 & 11.1 \\
\hline Undergraduate / College & 39 & 9.6 \\
\hline TOTAL & $\mathbf{4 0 7}$ & $\mathbf{1 0 0}$ \\
\hline
\end{tabular}

As shown in Table 6, the majority of the respondents have ongoing Master's units.

Table 6 Frequency and Percentage Distribution of Respondents in terms of Level of Education

\begin{tabular}{|l|l|l}
\hline Level of Education & Frequency & Percentage \\
\hline
\end{tabular}


medRxiv preprint doi: https://doi.org/10.1101/2021.04.22.21254017; this version posted April 25, 2021. The copyright holder for this preprint (which was not certified by peer review) is the author/funder, who has granted medRxiv a license to display the preprint in perpetuity.

It is made available under a CC-BY-NC-ND 4.0 International license.

\begin{tabular}{|l|c|c|}
\hline $\begin{array}{l}\text { Vocational or Bachelor's } \\
\text { Level }\end{array}$ & 1 & 2 \\
\hline Bachelor's Graduate & 102 & 25.1 \\
\hline Master Level & 150 & 36.9 \\
\hline Masteral Graduate & 69 & 17 \\
\hline Doctoral Level & 71 & 17 \\
\hline Doctoral Graduate & 14 & 3.4 \\
\hline TOTAL & $\mathbf{4 0 7}$ & $\mathbf{1 0 0}$ \\
\hline
\end{tabular}

Table 7 shows the salary range of Teachers in the Philippines, where the majority of the respondents have 10,000 to 20,000 , followed by 20,000 to 30,000 .

Table 7 Frequency and Percentage Distribution of Respondents in terms of Salary Range

\begin{tabular}{|l|c|c|}
\hline \multicolumn{1}{|c|}{ Salary Range } & Frequency & Percentage \\
\hline Less than 10,000 & 53 & 13 \\
\hline 10,001 to 20,000 & 271 & 66.6 \\
\hline 20,001 to 30,000 & 37 & 9.1 \\
\hline 30,001 to 40,000 & 18 & 4.4 \\
\hline 40,001 to 50,000 & 6 & 1.5 \\
\hline 50,001 to 75,000 & 16 & 3.9 \\
\hline 75,001 to 100,000 & 4 & 1.0 \\
\hline TOTAL & $\mathbf{4 0 5}$ & $\mathbf{9 9 . 5}$ \\
\hline
\end{tabular}

The majority of the respondents are engaged in teaching from 2 to 5 years.

Table 8 Frequency and Percentage Distribution of Respondents in terms of Preference of Length of Service

\begin{tabular}{|l|c|c|}
\hline \multicolumn{1}{|c|}{ Length of Service } & Frequency & Percentage \\
\hline Less than a year & 24 & 5.9 \\
\hline 1 to 2 years & 41 & 10.1 \\
\hline 2 to 5 years & 107 & 26.4 \\
\hline 6 to 10 years & 104 & 25.6 \\
\hline 11 to 15 years & 67 & 16.5 \\
\hline 16 to 20 years & 25 & 6.2 \\
\hline 21 to 30 years & 32 & 7.9 \\
\hline 30 years and above & 6 & 1.5 \\
\hline TOTAL & $\mathbf{4 0 6}$ & $\mathbf{1 0 0}$ \\
\hline
\end{tabular}

The distribution of respondents shows that all regions are distributed.

Table 9 Frequency and Percentage Distribution of Respondents in terms of Region

\begin{tabular}{|l|l|l|}
\hline Highest Academic & Frequency & Percentage \\
\hline
\end{tabular}


medRxiv preprint doi: https://doi.org/10.1101/2021.04.22.21254017; this version posted April 25, 2021. The copyright holder for this preprint (which was not certified by peer review) is the author/funder, who has granted medRxiv a license to display the preprint in perpetuity.

It is made available under a CC-BY-NC-ND 4.0 International license.

\begin{tabular}{|l|c|c|}
\hline \multicolumn{1}{|c|}{ Qualification } & & \\
\hline Region 1 & 71 & 17.4 \\
\hline CAR & 13 & 3.2 \\
\hline NCR & 33 & 8.1 \\
\hline Region 2 & 18 & 4.4 \\
\hline Region 3 & 38 & 9.3 \\
\hline Region 4A & 67 & 16.5 \\
\hline Region 4B & 6 & 1.5 \\
\hline Region 5 & 9 & 2.2 \\
\hline Region 6 & 21 & 5.2 \\
\hline Region 7 & 56 & 13.8 \\
\hline Region 8 & 41 & 10.1 \\
\hline Region 9 & 27 & 6.6 \\
\hline CARAGA & 4 & 1.0 \\
\hline ARMM & 1 & 0.2 \\
\hline TOTAL & $\mathbf{4 0 6}$ & $\mathbf{1 0 0}$ \\
\hline
\end{tabular}

The workplace stress of teachers is shown in the table, where most of the teachers need more time in order to finish the required task given to them. As stated in the literature review, the regular workload for teachers in elementary and secondary level is 6 hours a day or 30 hours a week, which still excludes other functions as a teacher (Department of Education, 2009). This implies that the workload of educators in the Philippines is overloaded and teachers need more time to finish the task assigned to them. Most of the educators agree that work is continuous as a teacher and does not practice their authority over their work where lack of acknowledgment and appreciation is also an issue as there is an impact of autocratic and democratic leadership style on their job satisfaction (Bhatti et al., 2012).

Workload also interferes with the family and social obligations of the teachers, where some of the teachers are bringing their paperwork at home. 75 percent of school hours are consumed in teaching and the remaining 25 percent of school hours are dedicated to paper works.

Table 10 Level of Workplace Stress of Teachers

\begin{tabular}{|l|c|c|}
\hline Indicators on Workplace Stress & Mean & $\begin{array}{c}\text { Descriptive } \\
\text { Equivalent }\end{array}$ \\
\hline $\begin{array}{l}\text { I can't honestly say what I really think } \\
\text { or get things off my chest at work. }\end{array}$ & 2.55 & Agree \\
\hline $\begin{array}{l}\text { My job has a lot of responsibility, but } \\
\text { I don't have very much authority }\end{array}$ & 2.77 & Agree \\
\hline I could usually do a much better job if & 3.18 & Agree \\
\hline
\end{tabular}


medRxiv preprint doi: https://doi.org/10.1101/2021.04.22.21254017; this version posted April 25, 2021. The copyright holder for this preprint (which was not certified by peer review) is the author/funder, who has granted medRxiv a license to display the preprint in perpetuity.

It is made available under a CC-BY-NC-ND 4.0 International license .

\begin{tabular}{|l|c|c|}
\hline I were given more time & & Agree \\
\hline $\begin{array}{l}\text { I seldom receive adequate } \\
\text { acknowledgment or appreciation } \\
\text { when my work is really good }\end{array}$ & 2.74 & Disagree \\
\hline $\begin{array}{l}\text { In general, I am not particularly proud } \\
\text { or satisfied with my job }\end{array}$ & 2.22 & Disagree \\
\hline $\begin{array}{l}\text { I have the impression that I am } \\
\text { repeatedly picked on or discriminated } \\
\text { against at work }\end{array}$ & 2.13 & Disagree \\
\hline $\begin{array}{l}\text { My workplace environment is not } \\
\text { very pleasant or safe }\end{array}$ & 2.64 & Agree \\
\hline $\begin{array}{l}\text { My job often interferes with my } \\
\text { family and social obligations, or } \\
\text { personal needs }\end{array}$ & 2.00 & Disagree \\
\hline $\begin{array}{l}\text { I tend to have frequent arguments with } \\
\text { superiors, coworkers or customers }\end{array}$ & $\mathbf{2 . 4 9}$ & Disagree \\
\hline $\begin{array}{l}\text { Most of the time I feel I have very } \\
\text { little control over my life at work }\end{array}$ & & \\
\hline Weighted Mean & & \\
\hline
\end{tabular}

Workplace depression of teachers is shown in table 11, where teachers are bothered by feeling tired or having little energy over the last two weeks. It is also shown that teachers do not have a severe depression towards work since most of them are educated and may be able to handle the situation even in hard times.

A number of suicide of educators is alarming results in the education sector of the Philippines (BusinessMirror, 2018). The Department of Education clarifies that the workload should not be blamed for the teacher's suicide because there are other factors that may contribute (Mateo, 2018; Reyes, 2018). While The Teachers' Dignity Coalition (TDC) met with DepEd officials to discuss concerns over the supposed workload, the department was urged to lighten teacher workloads (Hernando-Malipot, 2018). The result of the study does not support that workload should be blamed in the depression of the teachers who committed suicides. There is no direct effect of the workload, though it may be a contributory factor that a teacher might end his or her life due to workload.

Table 11 Level of Depression of the Teachers

\begin{tabular}{|c|c|c|}
\hline \multicolumn{1}{|c|}{ Depression Assessment } & Mean & $\begin{array}{c}\text { Descriptive } \\
\text { Equivalent }\end{array}$ \\
\hline $\begin{array}{l}\text { How often have you been bothered by } \\
\text { feeling down, depressed, irritable, or }\end{array}$ & 2.18 & Seldom \\
\hline
\end{tabular}


medRxiv preprint doi: https://doi.org/10.1101/2021.04.22.21254017; this version posted April 25, 2021. The copyright holder for this preprint (which was not certified by peer review) is the author/funder, who has granted medRxiv a license to display the preprint in perpetuity.

It is made available under a CC-BY-NC-ND 4.0 International license .

\begin{tabular}{|l|c|c|}
\hline hopeless over the last two weeks? & & Seldom \\
\hline $\begin{array}{l}\text { How often have you been bothered } \\
\text { that you have little interest or pleasure } \\
\text { in doing things over the last two } \\
\text { weeks? }\end{array}$ & 2.18 & \\
\hline $\begin{array}{l}\text { How often have you been bothered by } \\
\text { trouble falling asleep, staying asleep, } \\
\text { or sleeping too much over the last two } \\
\text { weeks? }\end{array}$ & 2.25 & Seldom \\
\hline $\begin{array}{l}\text { How often have you been bothered } \\
\text { that you have poor appetite, weight } \\
\text { loss, or overeating over the last two } \\
\text { weeks? }\end{array}$ & 2.12 & Seldom \\
\hline $\begin{array}{l}\text { How often have you been bothered by } \\
\text { feeling tired, or having little energy } \\
\text { over the last two weeks? }\end{array}$ & 2.50 & Sometimes \\
\hline $\begin{array}{l}\text { How often have you been bothered by } \\
\text { feeling bad about yourself - or feeling } \\
\text { that you are a failure, or that you have } \\
\text { let yourself or your family down over } \\
\text { the last two weeks? }\end{array}$ & 2.07 & Seldom \\
\hline $\begin{array}{l}\text { How often have you been bothered } \\
\text { that you have trouble concentrating on } \\
\text { things like school work, reading, or } \\
\text { watching TV over the last two weeks? }\end{array}$ & & Seldom \\
\hline $\begin{array}{l}\text { How often have you been bothered } \\
\text { that you have trouble concentrating on } \\
\text { things like school work, reading, or } \\
\text { watching TV over the last two weeks? }\end{array}$ & 1.87 & Seldom \\
\hline $\begin{array}{l}\text { How often have you been bothered by } \\
\text { thoughts that you would be better off } \\
\text { dead, or of hurting yourself in some } \\
\text { way over the last two weeks? }\end{array}$ & 1.64 & \\
\hline $\begin{array}{l}\text { How often have you been feel that } \\
\text { you want to give up? }\end{array}$ & & \\
\hline Weighted Mean & & \\
\hline
\end{tabular}

The table shows that there is a significant difference between the level of workplace stress across teaching level, educational attainment and salary range.

Based on the result of the study, the level of stress is high for the teachers teaching in Kindergarten, followed by the Junior and Senior levels compared to the elementary grade. It was also shown that Workplace stress is lower in vocational and college level compared to any other educational level. A typical full-time Instructor or Professor is handling 18 hours 
medRxiv preprint doi: https://doi.org/10.1101/2021.04.22.21254017; this version posted April 25, 2021. The copyright holder for this preprint (which was not certified by peer review) is the author/funder, who has granted medRxiv a license to display the preprint in perpetuity.

It is made available under a CC-BY-NC-ND 4.0 International license.

and are de-loaded by corresponding other functions such as research, extension (Tarlac State University, 2008), while the teacher in the kindergarten up to the senior high school are teaching 30 hours per week with an average of 6 hours a day.

Bachelor's graduate and master's level teachers have a higher level of workplace stress compared to those who are graduate with a master's degree and doctoral degree. Likewise, those earning below 20,000 has a higher level of stress compared to those who are earning 20,000 and above. The result of the study agrees with several studies that salary has a contribution to the level of stress of workers (Muhammad Shahzad Chaudhry; Hazoor Muhammad Sabir; Rafi, 2011; Parvin \& Karbin, 2011; Teck-Hong \& Waheed, 2011).

Table 12 Significant Difference between Level of Workplace Stress and profile variables

\begin{tabular}{|c|c|c|c|c|c|c|}
\hline $\begin{array}{c}\text { Profile } \\
\text { Variables }\end{array}$ & Groups & Mean & Result & $\begin{array}{c}\text { F- } \\
\text { value }\end{array}$ & $\begin{array}{c}\text { Sig. } \\
\text { Level }\end{array}$ & $\begin{array}{c}\text { Interpret } \\
\text { ation }\end{array}$ \\
\hline \multirow{2}{*}{ Sex } & Male & 2.42 & Disagree & \multirow{2}{*}{1.187} & \multirow{2}{*}{0.277} & \multirow{2}{*}{$\begin{array}{c}\text { Not } \\
\text { Significant }\end{array}$} \\
\hline & Female & 2.51 & Agree & & & \\
\hline \multirow{3}{*}{$\begin{array}{l}\text { Employment } \\
\text { Status }\end{array}$} & Regular/Permanent & 2.49 & Disagree & \multirow{3}{*}{0.118} & \multirow{3}{*}{0.889} & \multirow{3}{*}{$\begin{array}{c}\text { Not } \\
\text { Significant }\end{array}$} \\
\hline & $\begin{array}{l}\text { Probationary/ } \\
\text { Temporary }\end{array}$ & 2.40 & Disagree & & & \\
\hline & $\begin{array}{c}\text { Contractual/ } \\
\text { Contract of } \\
\text { Service/Part-Time }\end{array}$ & 2.48 & Disagree & & & \\
\hline \multirow{2}{*}{$\begin{array}{l}\text { Employment } \\
\text { Type }\end{array}$} & Government & 2.50 & Agree & \multirow{2}{*}{3.210} & \multirow{2}{*}{0.074} & \multirow{2}{*}{$\begin{array}{c}\text { Not } \\
\text { Significant }\end{array}$} \\
\hline & Private & 2.30 & Disagree & & & \\
\hline \multirow{7}{*}{$\begin{array}{l}\text { Teaching } \\
\text { Level }\end{array}$} & Kindergarden & 2.85 & Agree & \multirow{7}{*}{5.016} & \multirow{7}{*}{0.00} & \multirow{7}{*}{ Significant } \\
\hline & $\begin{array}{c}\text { Elementary (Grade } \\
1 \text { to } 3)\end{array}$ & 2.46 & Disagree & & & \\
\hline & $\begin{array}{c}\text { Elementary (Grade } \\
4 \text { to } 8 \text { ) } \\
\end{array}$ & 2.49 & Disagree & & & \\
\hline & $\begin{array}{c}\text { Junior High School } \\
\text { (Grade } 9 \text { and 10) }\end{array}$ & 2.63 & Agree & & & \\
\hline & $\begin{array}{c}\text { Senior High School } \\
\text { (Grade } 11 \text { and 12) }\end{array}$ & 2.62 & Agree & & & \\
\hline & Vocational Level & 2.22 & Disagree & & & \\
\hline & $\begin{array}{l}\text { Undergraduate / } \\
\text { College }\end{array}$ & 2.14 & Disagree & & & \\
\hline \multirow{6}{*}{$\begin{array}{l}\text { Level of } \\
\text { Education }\end{array}$} & $\begin{array}{c}\text { Vocational or } \\
\text { Bachelor's Level }\end{array}$ & 2.60 & Agree & \multirow{6}{*}{3.185} & \multirow{6}{*}{0.008} & \multirow{6}{*}{ Significant } \\
\hline & Bachelor's Graduate & 2.62 & Agree & & & \\
\hline & Masteral Level & 2.55 & Agree & & & \\
\hline & Masteral Graduate & 2.33 & Disagree & & & \\
\hline & Doctoral Level & 2.31 & Disagree & & & \\
\hline & Doctoral Graduate & 2.34 & Disagree & & & \\
\hline
\end{tabular}


medRxiv preprint doi: https://doi.org/10.1101/2021.04.22.21254017; this version posted April 25, 2021. The copyright holder for this preprint (which was not certified by peer review) is the author/funder, who has granted medRxiv a license to display the preprint in perpetuity.

It is made available under a CC-BY-NC-ND 4.0 International license .

\begin{tabular}{|c|c|c|c|c|c|c|}
\hline \multirow{7}{*}{$\begin{array}{l}\text { Salary } \\
\text { Range }\end{array}$} & Less than 10,000 & 2.50 & Agree & \multirow{7}{*}{2.192} & \multirow{7}{*}{0.043} & \multirow{7}{*}{ Significant } \\
\hline & 10,001 to 20,000 & 2.52 & Agree & & & \\
\hline & 20,001 to 30,000 & 2.25 & Disagree & & & \\
\hline & 30,001 to 40,000 & 2.13 & Disagree & & & \\
\hline & 40,001 to 50,000 & 2.05 & Disagree & & & \\
\hline & 50,001 to 75,000 & 2.61 & Agree & & & \\
\hline & 75,001 to 100,000 & 2.98 & Agree & & & \\
\hline \multirow{8}{*}{$\begin{array}{l}\text { Length of } \\
\text { Service }\end{array}$} & Less than a year & 2.38 & Disagree & \multirow{8}{*}{1.197} & \multirow{8}{*}{0.303} & \multirow{8}{*}{$\begin{array}{c}\text { Not } \\
\text { Significant }\end{array}$} \\
\hline & 1 to 2 years & 2.53 & Agree & & & \\
\hline & 2 to 5 years & 2.47 & Disagree & & & \\
\hline & 6 to 10 years & 2.57 & Agree & & & \\
\hline & 11 to 15 years & 2.55 & Agree & & & \\
\hline & 16 to 20 years & 2.38 & Disagree & & & \\
\hline & 21 to 30 years & 2.32 & Disagree & & & \\
\hline & 30 years and above & 2.05 & Disagree & & & \\
\hline \multirow{14}{*}{ Region } & Region 1 & 2.40 & Disagree & \multirow{14}{*}{0.632} & \multirow{14}{*}{0.827} & \multirow{14}{*}{$\begin{array}{c}\text { Not } \\
\text { Significant }\end{array}$} \\
\hline & CAR & 2.49 & Disagree & & & \\
\hline & NCR & 2.63 & Agree & & & \\
\hline & Region 2 & 2.56 & Agree & & & \\
\hline & Region 3 & 2.52 & Agree & & & \\
\hline & Region 4A & 2.44 & Disagree & & & \\
\hline & Region 4B & 2.13 & Disagree & & & \\
\hline & Region 5 & 2.21 & Disagree & & & \\
\hline & Region 6 & 2.52 & Agree & & & \\
\hline & Region 7 & 2.49 & Disagree & & & \\
\hline & Region 8 & 2.54 & Agree & & & \\
\hline & Region 9 & 2.62 & Agree & & & \\
\hline & CARAGA & 2.38 & Disagree & & & \\
\hline & ARMM & 2.70 & Agree & & & \\
\hline
\end{tabular}

The table shows that there is a significant difference between the level of workplace depression across employment type, teaching level, educational attainment, and salary range.

Based on the result of the study, the level of depression is high for the teachers teaching in the government sector than in the private institutions. It was also presented that Junior and elementary grade levels are more depressed than other educators. It was also shown that Workplace depression is lower in vocational and college level compared to any other educational level. A workload and stress may have a contributory factor in the level of depression especially among those working full time (Caspi et al., 2003; Kubo, 2007; Van Praag, 2004). 
medRxiv preprint doi: https://doi.org/10.1101/2021.04.22.21254017; this version posted April 25, 2021. The copyright holder for this preprint (which was not certified by peer review) is the author/funder, who has granted medRxiv a license to display the preprint in perpetuity.

It is made available under a CC-BY-NC-ND 4.0 International license .

Bachelor's graduate and master's level teachers have a higher level of depression compared to those who are graduate in a master's degree and doctoral degree. Likewise, those earning below 20,000 has a higher level of depression compared to those who are earning 20,000 and above. Despite the result of the study shows that those earning 50,000 and above have a higher level of depression compared to the other range, the limitation of this research is very limited to the few numbers of respondents that may not represent the overall population.

Table 13 Significant Difference between Frequency of Depression and profile variables

\begin{tabular}{|c|c|c|c|c|c|c|}
\hline $\begin{array}{c}\text { Profile } \\
\text { Variables }\end{array}$ & Groups & Mean & & $\begin{array}{c}\text { F- } \\
\text { value }\end{array}$ & $\begin{array}{c}\text { Sig. } \\
\text { Level }\end{array}$ & $\begin{array}{c}\text { Interpret } \\
\text { ation }\end{array}$ \\
\hline \multirow{2}{*}{ Sex } & Male & 2.09 & Seldom & \multirow{2}{*}{0.011} & \multirow{2}{*}{0.915} & \multirow{2}{*}{$\begin{array}{c}\text { Not } \\
\text { Significant }\end{array}$} \\
\hline & Female & 2.10 & Seldom & & & \\
\hline \multirow{3}{*}{$\begin{array}{l}\text { Employment } \\
\text { Status }\end{array}$} & Regular/Permanent & 2.08 & Seldom & \multirow{3}{*}{1.57} & \multirow{3}{*}{0.21} & \multirow{3}{*}{$\begin{array}{c}\text { Not } \\
\text { Significant }\end{array}$} \\
\hline & $\begin{array}{l}\text { Probationary/ } \\
\text { Temporary }\end{array}$ & 2.08 & Seldom & & & \\
\hline & $\begin{array}{c}\text { Contractual/ } \\
\text { Contract of } \\
\text { Service/Part-Time }\end{array}$ & 2.40 & Seldom & & & \\
\hline \multirow{2}{*}{$\begin{array}{c}\text { Employment } \\
\text { Type }\end{array}$} & Government & 2.17 & Seldom & \multirow{2}{*}{4.46} & \multirow{2}{*}{0.035} & \multirow{2}{*}{ Significant } \\
\hline & Private & 1.84 & Seldom & & & \\
\hline \multirow{7}{*}{$\begin{array}{l}\text { Teaching } \\
\text { Level }\end{array}$} & Kindergarden & 2.17 & Seldom & \multirow{7}{*}{6.44} & \multirow{7}{*}{0.000} & \multirow{7}{*}{ Significant } \\
\hline & $\begin{array}{c}\text { Elementary (Grade } \\
1 \text { to } 3)\end{array}$ & 2.27 & Seldom & & & \\
\hline & $\begin{array}{c}\text { Elementary (Grade } \\
4 \text { to } 8)\end{array}$ & 2.22 & Seldom & & & \\
\hline & $\begin{array}{c}\text { Junior High School } \\
\text { (Grade } 9 \text { and 10) }\end{array}$ & 2.33 & Seldom & & & \\
\hline & $\begin{array}{l}\text { Senior High School } \\
\text { (Grade } 11 \text { and 12) }\end{array}$ & 2.05 & Seldom & & & \\
\hline & Vocational Level & 1.72 & Never & & & \\
\hline & $\begin{array}{c}\text { Undergraduate / } \\
\text { College }\end{array}$ & 1.61 & Never & & & \\
\hline \multirow{6}{*}{$\begin{array}{l}\text { Level of } \\
\text { Education }\end{array}$} & $\begin{array}{c}\text { Vocational or } \\
\text { Bachelor's Level }\end{array}$ & 2.60 & Sometimes & \multirow{6}{*}{7.90} & \multirow{6}{*}{0.000} & \multirow{6}{*}{ Significant } \\
\hline & Bachelor's Graduate & 2.62 & Sometimes & & & \\
\hline & Masteral Level & 2.55 & Sometimes & & & \\
\hline & Masteral Graduate & 2.33 & Seldom & & & \\
\hline & Doctoral Level & 2.31 & Seldom & & & \\
\hline & Doctoral Graduate & 2.34 & Seldom & & & \\
\hline \multirow{5}{*}{$\begin{array}{l}\text { Salary } \\
\text { Range }\end{array}$} & Less than 10,000 & 2.09 & Seldom & \multirow{5}{*}{4.29} & \multirow{5}{*}{0.000} & \multirow{5}{*}{ Significant } \\
\hline & 10,001 to 20,000 & 2.14 & Seldom & & & \\
\hline & 20,001 to 30,000 & 1.83 & Seldom & & & \\
\hline & 30,001 to 40,000 & 1.66 & Never & & & \\
\hline & 40,001 to 50,000 & 1.31 & Never & & & \\
\hline
\end{tabular}


medRxiv preprint doi: https://doi.org/10.1101/2021.04.22.21254017; this version posted April 25, 2021. The copyright holder for this preprint (which was not certified by peer review) is the author/funder, who has granted medRxiv a license to display the preprint in perpetuity.

It is made available under a CC-BY-NC-ND 4.0 International license .

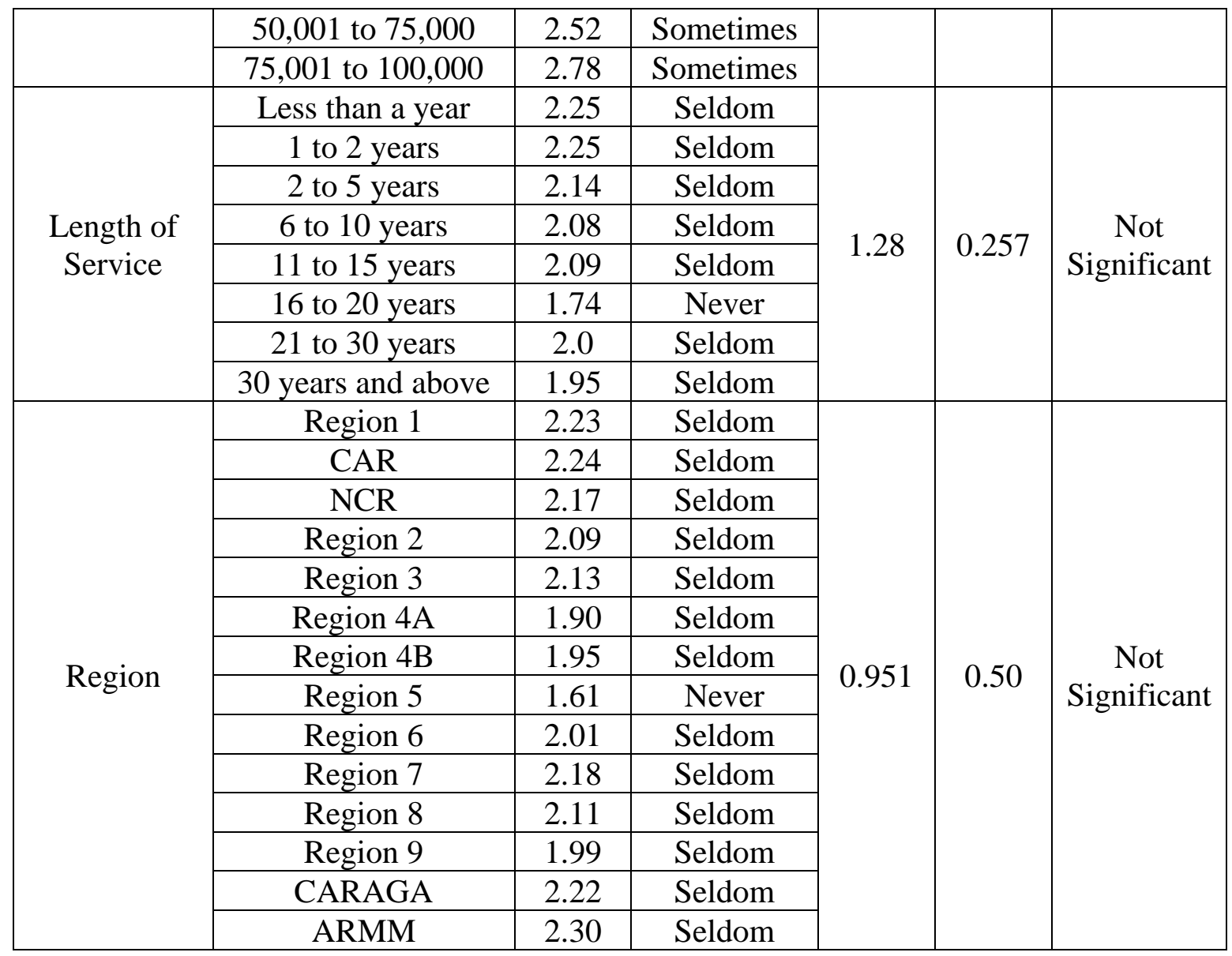

Based on the overall result of the study, stress and depression of teachers are connected to each other, but as a limitation of this study, causes are not identified. Stress is the body's response to physical or emotional demands and emotional stress can play a role in causing depression or be a symptom of it. A stressful situation, especially in the workload of the teachers, can trigger feelings of depression, and these feelings can make it more difficult to deal with stress.

\section{Conclusions and Recommendations}

Teaching is the noblest profession because it is the source of all professionals in the world. Without teachers, there will be no knowledge that was imparted and transferred. As a conclusion of this study, the level of stress and depression is high for the teachers teaching at lower levels such as kindergarten, elementary and high school. It was also shown that Workplace stress and depression is lower in vocational and college level. It is recommended that the government and administrator should look at the possible intervention to minimize the level of stress and depression of educators. 
medRxiv preprint doi: https://doi.org/10.1101/2021.04.22.21254017; this version posted April 25, 2021. The copyright holder for this preprint (which was not certified by peer review) is the author/funder, who has granted medRxiv a license to display the preprint in perpetuity.

\section{References}

Bhatti, N., Maitlo, G. M., Shaikh, N., Hashmi, M. A., \& Shaikh, F. M. (2012). The Impact of Autocratic and Democratic Leadership Style on Job Satisfaction. International Business Research. https://doi.org/10.5539/ibr.v5n2p192

BusinessMirror. (2018). Suicide of teachers, children prompts call for govt action | BusinessMirror. https://businessmirror.com.ph/suicide-of-teachers-children-promptscall-for-govt-action/

Caspi, A., Sugden, K., Moffitt, T. E., Taylor, A., Craig, I. W., Harrington, H. L., McClay, J., Mill, J., Martin, J., Braithwaite, A., \& Poulton, R. (2003). Influence of life stress on depression: Moderation by a polymorphism in the 5-HTT gene. Science.

https://doi.org/10.1126/science.1083968

Commission on Higher Education. (2016). CHED K to 12 Transition Program. CHED K to 12 Transition Unit. https://chedk12.wordpress.com/sgs/

Department of Budget Management. (2012). Chapter 7 Position Classification and Compensation Scheme for Faculty Positions in State Universities and Colleges. https://www.dbm.gov.ph/wp-content/uploads/2012/03/Manual-on-PCC-Chapter-7.pdf Department of Education. (2009). February 24, 2009 DO 16, s. 2009 - Addendum to DepEd Memorandum No. 291, s. 2008 (Guidelines for the Implementation of CSC Resolution No. 080096 on Working Hours for Public School Teachers). DepEd Memorandum. http://www.deped.gov.ph/2009/02/24/do-16-s-2009-addendum-to-deped-memorandumno-291-s-2008-guidelines-for-the-implementation-of-csc-resolution-no-080096-onworking-hours-for-public-school-teachers/

Hatton, V., Heath, M. A., Gibb, G. S., Coyne, S., Hudnall, G., \& Bledsoe, C. (2017). Secondary Teachers' Perceptions of their Role in Suicide Prevention and Intervention. School Mental Health. https://doi.org/10.1007/s12310-015-9173-9

Hernando-Malipot, M. (2018). DepEd urged to reduce teachers' workload 》 Manila Bulletin News. Manila Bulletin. https://news.mb.com.ph/2018/08/02/deped-urged-to-reduceteachers-workload/

Kubo, C. (2007). Stress and depression. In Nippon rinsho. Japanese journal of clinical medicine. https://doi.org/10.1146/annurev.clinpsy.1.102803.143938

Leung, J. P. (1994). Teacher suicide in Hong Kong: Causes and prevention. In Bulletin of the Hong Kong Psychological Society. https://doi.org/10.1007/978-3-319-23766-4_66 
medRxiv preprint doi: https://doi.org/10.1101/2021.04.22.21254017; this version posted April 25, 2021. The copyright holder for this preprint (which was not certified by peer review) is the author/funder, who has granted medRxiv a license to display the preprint in perpetuity.

It is made available under a CC-BY-NC-ND 4.0 International license .

Mateo, J. (2018). DepEd probes teacher suicides. The Philippine Star.

https://www.philstar.com/other-sections/education-andhome/2018/08/30/1846977/deped-probes-teacher-suicides

McIntosh, W. L., Spies, E., Stone, D. M., Lokey, C. N., Trudeau, A.-R. T., \& Bartholow, B. (2016). Suicide Rates by Occupational Group — 17 States, 2012. MMWR. Morbidity and Mortality Weekly Report, 65(25), 641-645. https://doi.org/10.15585/mmwr.mm6525a1

Mendoza, R. D. (2019a). The variation between public and private secondary school teachers in Sulu: Evidence from verbal English fluency, workplace stress, coping mechanism and job performance. In Asian EFL Journal.

Mendoza, R. D. (2019b). Verbal english fluency, workplace stress, and coping mechanism of secondary school faculty in Sulu. Asian EFL Journal.

Moeny, J. (2014). Global Study: U.S. Teachers Work More Hours, With Less Financial Return - Teaching Now - Education Week Teacher. Education Week. https://blogs.edweek.org/teachers/teaching_now/2014/09/international_report_us_teache rs_work_more_earn_less.html

Muhammad Shahzad Chaudhry; Hazoor Muhammad Sabir; Rafi, N. M. N. K. (2011). Exploring The Relationship Between Salary Satisfaction And Job Satisfaction: A Comparison Of Public And Private Sector Organizations. The Journal of Commerce. Organisation for Economic Co-operation and Development. (2007). Education at a Glance. https://doi.org/10.1787/068521306487

Organisation for Economic Co-operation and Development. (2012). Education at a Glance :

OECD Indicators. Organisation for Economic Co-Operation and Development, 2010(Pisa 2009), 1-10. https://doi.org/10.1787/eag-2009-en

Organisation for Economic Co-operation and Development. (2014). OECD Education at a glance. October. https://doi.org/10.1787/edu-data-en

Orlanda-Ventayen, C. C. (2019). Impact of English language courses and English proficiency on academic performance of junior business administrators. Asian EFL Journal, 24(4.1).

Parvin, M. M., \& Karbin, M. M. N. (2011). Factors Affecting Employee Job Satisfaction of Pharmaceutical Sector. Journal of Business and Management Research.

Platt, B., Hawton, K., Simkin, S., \& Mellanby, R. J. (2012). Suicidal behaviour and psychosocial problems in veterinary surgeons: A systematic review. In Social Psychiatry and Psychiatric Epidemiology. https://doi.org/10.1007/s00127-010-0328-6

Reyes, R. (2018). DepEd mourns teacher who killed self - SUNSTAR. Sun Star Tacloban. 
medRxiv preprint doi: https://doi.org/10.1101/2021.04.22.21254017; this version posted April 25, 2021. The copyright holder for this preprint (which was not certified by peer review) is the author/funder, who has granted medRxiv a license to display the preprint in perpetuity. It is made available under a CC-BY-NC-ND 4.0 International license .

https://www.sunstar.com.ph/article/1753361

Shilubane, H. N., Bos, A. E., Ruiter, R. A., van den Borne, B., \& Reddy, P. S. (2015). High school suicide in South Africa: teachers' knowledge, views and training needs. BMC Public Health. https://doi.org/10.1186/s12889-015-1599-3

Tarlac State University. (2008). Research Manual. Tarlac State University. https://www.tsu.edu.ph/media/300274/Operations-Manual-Research-ExtensionProduction-and-VP-Academic-Affairs.pdf

Teck-Hong, T., \& Waheed, A. (2011). Herzberg's motivation-hygiene theory and job satisfaction in the Malaysian retail sector: The mediating effect of love of money. Asian Academy of Management Journal. https://doi.org/10.5897/JAERD12.088

Terrazola, V. E. (2018). DepEd, DOH to address teacher suicides. Manila Bulletin News. https://news.mb.com.ph/2018/09/19/deped-doh-to-address-teacher-suicides/

Tiesman, H. M., Konda, S., Hartley, D., Menéndez, C. C., Ridenour, M., \& Hendricks, S. (2015). Suicide in U.S. Workplaces, 2003-2010. American Journal of Preventive Medicine, 48(6), 674-682. https://doi.org/10.1016/j.amepre.2014.12.011

Van Praag, H. M. (2004). Can stress cause depression? In Progress in NeuroPsychopharmacology and Biological Psychiatry. https://doi.org/10.1016/j.pnpbp.2004.05.031

Ventayen, R. J. M., \& Orlanda-ventayen, C. C. (2018). Graduate students' perspective on the usability of Grammarly® in one ASEAN state university. Asian ESP Journal, 14(7.2). http://www.scopus.com/inward/record.url?eid=2-s2.085061485593\& partnerID=MN8TOARS 